\title{
An Integrated Competency-Based Training Model for theological training
}

\begin{abstract}
Authors:
James K. Mwangi ${ }^{1}$

Ben J. de Klerk ${ }^{1}$

Affiliations:

${ }^{1}$ Department of Practical

Theology, Potchefstroom

Campus, North-West

University, South Africa

Note:

This article is published in the

Section Practical Theology

of the Society for Practical

Theology in South Africa.

Correspondence to:

Ben de Klerk

Email:

ben.deklerk@nwu.ac.za

Postal address:

PO Box 20764, Noordbrug

2522, South Africa

Dates:

Received: 17 Feb. 2011

Accepted: 28 July 2011

Published: 10 Nov. 2011

How to cite this article: Mwangi, J.K. \& De Klerk, B.J., 2011, 'An Integrated Competency-Based Training Model for theological training', HTS Teologiese Studies/Theological Studies 67(2), Art. \#1036, 10 pages. http://dx.doi.org/10.4102/ hts.v67i2.1036
\end{abstract}

(C) 2011. The Authors. Licensee: AOSIS OpenJournals. This work is licensed under the Creative Commons Attribution License.
This article examines the relationship between theological training and practical ministry with the purpose of addressing the fundamental problems that hinder theological training from becoming relevant. There exists a general concern about the way theological schools are preparing men and women for church ministry, with the church leadership feeling like graduates are not up to the task of ministering despite the theological training. The research has established that there is a relationship between theological training and practice of ministry and that practical ministry can only be improved through enhancing theological training. Ultimately the article establishes the need for a competent training programme modelled after the New Testament Discipleship Model approach. This model integrates knowledge, being and practical training. The article tries to outline a model of training (i.e. the Integrated Competency-Based Training Model) that will seek to address many of the inadequacies in the training of church ministers with the aim of making theological training translate into the practice of ministry.

\section{Introduction}

The task of theological training is to nurture gifted leaders who are in turn to nurture other believers so that the church can effectively fulfill her missional mandate. Because of the relationship between theological training and the practice of ministry, enriching theological training will enhance the ministry in the churches, thus translating theological training into practical ministry. The effectiveness of theological training must therefore be measured by how it enhances the practice of ministry in the work of its graduates. The question of the relationship between theological training and practical ministry has arisen from a concern about the quality of theological training. Over time, there has been growing dissatisfaction with the state of the theological training, also in East and Central Africa. Dissatisfaction has mainly been coming from the churches which are the producers and the recipients of the theological schools graduates. The seminary has come to be viewed as irrelevant in training people for church ministry. The trainers have been accused of being 'theoretical' rather than 'practical' in training for ministry (Murdock Charity Trust 1995:9-24). The graduates, in turn, point an accusing finger at theological institutions which they feel do not adequately prepare them to deal with life issues that they encounter in ministry (Morgan \& Giles 1994:71-72).

The problem statement of this article could therefore be formulated as follows: 'What are the guidelines and possible model that should guide the harmonisation of the theological training with biblical principles and needs of practical ministry in East and Central Africa?' The aim of this article is to establish the relationship between theological training and practical ministry and to develop guidelines for a model of theological training. Details for the new model are identified from other models and collated to form a new model believed to enhance training that leads to practical ministry.

This article is divided into two sections; the first part examines training approaches that have been used in church history in training for ministry and also examines different models that have recently emerged in the training for ministry. The second part uses some of the positive aspects observed from the aforementioned models to come up with a new model of theological training.

\section{Historical paradigms for ministerial training or formation}

There are a number of models recognised for ministerial formation; for example, Sidney Rooy (1988:50-71) has identified and analysed four paradigms which have been apparent since the inception of the church. These include catechetical, monastic, scholastic and the seminary models of training. The Catechetical Model of education was developed during the period referred to as the post-apostolic period, after the year AD 200. This form of church related education was directed towards the Christians at the grass root level. The education was necessitated by the 
need for the continuity of the apostolic message that was under threat from Gnostic teaching and people with pagan background. Cole (2001) points out that the emphasis on instruction of new converts was done in catechumenal schools whilst instruction in doctrine and Christian life was done in Catechetical schools and focused on Christian leaders. The Monastic Model came as a result of decadency that had crept into the church largely due to the adoption of Christianity by the Roman Empire as the official state religion. A lay movement called monasticism developed in response to the worldliness of the church by advocating denial and encouraging asceticism. In due course the monastic ideal spread from the East to the West, becoming an educational force and setting the stage for higher level of learning.

The Scholastic Model is an outgrowth of the monastic schools that occurred in the 12th century. With the revival of cities, the monastic schools which were mostly located in the rural areas began to decline as centers of learning. Cathedral schools in the cities were quickly taking their place. The cathedral schools were mainly concerned with:

secondary education that focused on seven liberal arts which had been inherited from the Roman educational system. These became the starting points for the medieval universities ... Medieval universities were the major institutions of liberal and professional studies at the time. Scholasticism was the dominant intellectual and educational method.

(Cole 2001:90; Rooy 1988:59)

The Seminary Model develops in the 16th century when the need arose for a radical change on the training of the clergy. The clerical life is reported to have lacked in the qualities that made for an edifying and fruitful apostolate. Theory and practice were united in a programme lasting ten years: three years of philosophy, four of scholastic theology and three of moral theology (Rooy 1988:63).

In contemporary theological education, Grahame Cheesman (1993:486-499) has identified five dominant models, namely: the Academic Model, Monastic Model, Training Model, Business Model and the Discipleship Model. These models are similar to Rooy's paradigms described earlier with the exception of the Business Model and the discipleship paradigm. The Business Model of theological education is a business enterprise focused on leadership and management. The Discipleship Model is a praxis-based pedagogy that upholds the concept of learning as an apprentice than as a student. Priority is given to the students' holistic growth for effective ministry rather than the more common emphasis on teacher conveying information for the students to seek to apply by them. In the current debate on theological education, Robert Banks (1999) has categorised the theological training into two major paradigms: classical and vocational models.

\section{A dominant model - The Scholastic Model}

Of the various models described earlier and despite the development of a number of variants to the models, scholastic or seminary form is recognised as appropriate by majority of protestant theological institutions worldwide for ministerial formation. This reflects a preoccupation with an educational paradigm modelled on schooling. The schooling mindset is the most prevalent within theological institutions. Banks (1999) underscores this as he notes common aspects in theological institutions:

With few exceptions, they all formally recruit qualified faculty, use critical methodologies, and value academic accreditation. Most still tend to view pastoral ministry as a profession and provide training in relevant skills. Only rarely do they question the dominant schooling paradigm by which they fashion their lives. Seminaries have often adopted secular models of education, rather than subject them to rigorous theological or practical evaluation: even where questioning takes place, it often parallels what is taking place in higher education or training for professions generally, not on any distinctive grounds.

(Banks 1999:6f)

An illustration of the Scholastic Model of theological training is as follows.

Figure 1 is adopted from Robert Banks (1999) and modified to illustrate the deficiency observed in the Schooling Model that most of the theological schools have adopted. It cleared demonstrates the imbalance in the 'know', 'do' and 'being'.

Banks' criticism suggests that the schooling paradigm has greatly contributed to the discontent expressed by

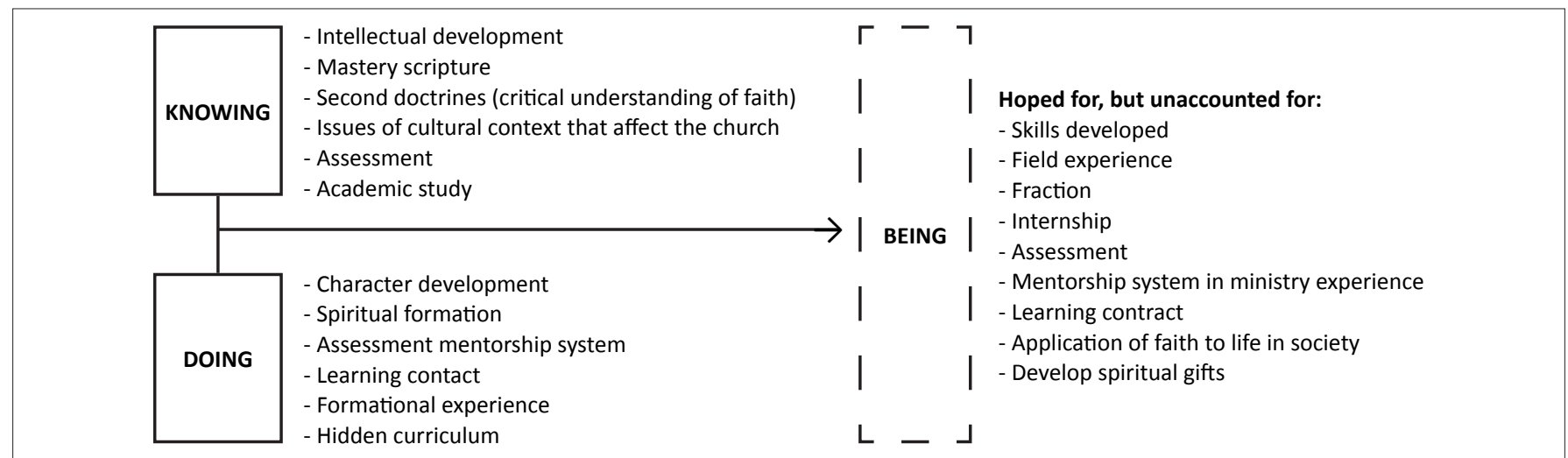

Source: Adopted from a diagram by Robert Banks (1999), The Theological University of Utrecht, the Netherlands

FIGURE 1: Illustration of a traditional model of theological training. 
stakeholders about ministerial training. The primary focus was more on intellectual development and acquisition of knowledge:

In contrast to intellectualist Greek epistemology, stressing the abstract and objective features of knowledge, the Hebrew concept of knowing integrates thought and experience ... This implies pedagogy of praxis: of reflection followed by action, of learning followed by doing, of theory alternating with practice.

(Hill 1997:177)

The Schooling or Academic Model gave theological education a positive influence demonstrating the fact that the study of theology can and should be academically rigorous. At its best, the Academic Model enhances both knowledge and the ability to think. However, it must be noted that the Academic Model has a negative influence on theological education. Within this model success in preparation for one's practical ministry is measured in terms of educational attainment. Other problems with the Academic Model are that the model projects the educator primarily as a lecturer, who necessarily becomes the role model for the aspiring minister. Consequently, the student enters the ministry seeing the task as primarily an intellectual one. In spite of its prominence, the Academic Model is inadequate in training ministers of the church. Unfortunately, as Cheesman (1993:486) notes, the tragedy of our theological education is that this model, only partly justified in the Western culture, has been imported all over the world in the founding of East and Central African Theological Colleges.

\section{Selected models that are critical of the schooling paradigm of ministerial training}

Since the problems of ministerial training were uncovered by Niebuhr, Williams and Gustafson (1957) and Feilding (1966), two approaches have been proposed as solutions to the negative evaluations. The first proposal was an increase in emphasis on field, or experiential education. The second proposal was a total restructuring of the Seminary Model of Training. A number of innovative models of instruction applicable to ministerial training have been designed. We have in mind internship, practicum, apprenticeship, mastery learning and theological education by extension, amongst others. Only a few examples are briefly mentioned.

\section{Theological Education by Extension}

Criticism for the Schooling Model in Guatemala in 1963 is what gave birth to the unconventional model of training for ministry that is called Theological Education by Extension (TEE). This model came into existence in response to a genuine need in the church in Central American Republic. It has been judged by many missiologists to be one of the most significant missiological developments of the 1960s and the most significant development in theological education in the 20th century. TEE has been defined as a decentralised theological education with a field base approach that does not interrupt the learner's productive relation to society.
A narrower and more precise definition is that TEE is 'that model of theological education which provides systematic, independent plus regular supervised seminars in the context of people's varied life and work' (Kinsler 1983:xiv).

TEE identifies the major weakness of the conventional method of training for ministry as overemphasis on the intellectual aspect of training to the detriment of spiritual and practical aspects of ministry training. By training persons where they lived, TEE was able to enlist and equip for ministry a greater number of persons suited and gifted to minister. At the heart of TEE is independent study. Instead of being confined to the classroom, TEE chose the seminar educational process. This process commonly known as the 'split rail fence' is said to unite the cognitive input and the field experience. TEE has also ably demonstrated the Apprenticeship Model. Whilst Theological Education by Extension has contributed to the training of church workers, especially in the third world countries, it has also had its inadequacies and therefore a reason for alternative models of training. It is marked by indiscipline, unaccountable study and poor mentoring of educational experiences. In addition to the weakness mentioned, TEE as a programme in many extensions in Africa has been reduced to acquisition of knowledge as an end in itself. Other arguments for the failure of TEE is that it does not train pastoral candidates quickly enough; that it is a second rate programme of training and that it does not contribute to the growth of the church.

\section{Elements of a learning experience}

Mayers unveiled a model for cross-cultural education called 'Elements of a learning Experience' (Mayers, Richards \& Webber 1972:120-126). This model was based upon Mayers' observations of how cultures vary. He inferred that the rise of the traditional schooling model was no accident. This model which emphasises classroom instruction, timed assignments, a prescribed curriculum, time periods, courses, and exams and an authoritative, impersonal professor, grew directly out of the dichotomising, sequential, goal and time-oriented values, so a Schooling Model evolved which reflected the same values. The Instructional Model, for example, is matching Western culture. At the opposite end of the spectrum from the West is a culture which will tend to be holistic, people-oriented and views prestige as ascribed and vulnerability as a strength. Such a culture fits the Africa context. Thus, in Mayers's model for a holistic culture, the place of instruction would include field trips, off-campus locations and the 'city' and would replace the classroom. Assignments would grow out of discussions, projects, and world concerns. Students would have freedom to select and develop projects within general guidelines. The instructor and the student will cooperate together. The teacher would share learning responsibility with the student, have much personal contact with the student and the course would end only after the student demonstrates proficiency understanding that the course would be only the beginning of learning (Mayers, Richards \& Webber 1972:127). Students training for ministry should spend more time actually doing ministry than merely studying about ministry. 
A further strength is that this perspective of Mayers's model enhances close interpersonal relationship between teachers and learners, where the teacher is viewed as a facilitator and guide in the learning process. In addition, this model calls for flexible content where the course is structured according to the developing needs of the student and the current issues in the church and society.

\section{A Functioning Model - Bibliche Ausbildung am Ort}

Bibliche Ausbildung am Ort [Bible Training on Location in English, or BAO] is a model currently being used in Austria, Germany and Switzerland to help train leaders and Christian workers in the context of the local church. According to Joe Wright, a missionary veteran in Austria, this is a functioning programme that is impacting people's lives. He contends that in the last ten years BAO has had 565 course participants per year in Austria, Germany and Switzerland (Wright 2007:289).

The church had key issues that demanded specific and focused training and the BAO wanted to train people in character development and ministry skills, not just in knowledge. They called for an integrated training noting that overemphasis of theory was a big weakness in learning institutions. BAO has other options like the Evangelical Academy or the partnership worked out with other institutes like Columbia International University where BAO courses are could be applied to the Master of Arts Degree (Wright 2007:292).

The BAO model makes emphasis on four fronts:

1. It is church-based.

2. It includes the head, the heart and the hand.

3. It includes training for course leaders.

4. It follows a six-step lesson.

All those participating in the study are supposed to interact with course materials at home or workplace and in the overall setting of the church. The programme normally takes place in the local church under the authority of the local church leadership. BAO has understood the centrality of the church in the business of training her workers. The early church seems to have used this kind of church-based model to train her leaders. The Scriptures are clear on how the apostle Paul trained Timothy and the other leaders. Key texts used to support this model include exegetical passages like 2 Timothy 2:2 and Ephesians 4:11-13, where church leaders have the responsibility to train believers. This model avails the opportunity for an apprentice approach to learning and training in ministry. Here, training within familiar contexts enhances character development and skills in ministry.

\section{Church-Based Theological Model}

This model of training is probably the latest initiative that seeks to offer an alternative to the Western traditional theological training model. The model uses the nonformal education paradigm with serious ordered learning that fits culture whilst combining elements of formal and informal. This new paradigm is a call to return to training leaders in the way of Christ and apostles following the model of the Antioch church in Acts 13:1-14:28. Leading proponents of Church-Based-Theological Education Model include BILD International based in the United States of America. In this article we will use BILD as a representative of the ChurchBased Model of Training.

The model is made up of resources designed to integrate with a community-based process of equipping ministers of the gospel, with the aim to accomplish two primary objectives:

- To equip the apprentice in a sound church-based philosophy of ministry, godly character, and essential skills required of those with equipping gifts.

- To guide the apprentice in the formation of a biblical theology of the Bible and in the completion of a 'Comprehensive Belief Framework in Culture', to address contemporary cultural issues on the foundation of the biblical narrative. They also are arranged according to three different emphases: character, ministry and academic.

The Church-Based Model of Training follows a learning system based on three steps (Reed 1995:7-13):

1. an in-service or ministry training taking place in the context of ministry

2. mastery of the Scriptures, which involves character development, ministry skills and biblical mastery

3. mentoring and assessment or qualification and assessment.

The Church-Based Model of Training is one good example of a model that takes theological training back to the church, where it belongs. Church-based training calls for training to be done in the church (the power of context), under the church (the power of responsibility), through the church (the power of community), with other churches (power of partnership), for the church (the power of mission), and to the glory of God (the power of worship).

The effectiveness of this form of training may be attributed to the fact that the programmes are designed to be led by church, leaders training future leaders in the context of their churches and not in sort of a school. The effectiveness of this programme could be attributed to its competency-based design where the focus is not on courses and grades but on measuring competence based on designed outcomes.

\section{Proposed model of theological training}

\section{A call for a new model}

In 1976, Jonathan Chao wrote that:

It is not possible to improve 'theological education' in isolation from its ministerial context. Rather, a complete, integrated approach to the development of indigenous leadership within the overall context of the church and her ministry must be undertaken ... A critical and historical analysis of the traditional missionary model of ministry exported from the West shows that it is built on the administrative structure reflecting the Roman mentality rather than the functional structure of service as found 
in the New Testament ... This kind of rethinking, although by no means new implies that any attempt to 'improve' the present form of theological education is not enough. What we need is not renovation but innovation.

(Chao 1976:66)

The implications of this comment are that the current Western model of training in the East and Central African countries needs a complete overhaul. The question of the relationship between theological training and practical ministry has arisen from a concern for quality in theological training. This concern is not only with the academic aspects of the training but also with the spiritual and practical aspects. These concerns have for some time gained wide attention and have been discussed at length by various theological trainers in Africa, the East and the West. The efforts reflect dissatisfaction with the status quo of theological training and a quest for improvement. The 'wind of change' has been blowing in evangelical theological education for over two decades. The institution's programme should evidence a holistic approach combining both curriculum and extracurricular activities in an educational plan which embraces objectives concerned with spiritual and vocational as well as academic development. Thus, theological training must be intentional and deliberate in fostering the spiritual formation of the students.

Irrespective of the cultural settings, whether in Africa, the West or the Eastern world, theological institutions exist to serve the church by training servants of the Lord and the church. This becomes a universal expectation. Dearborn (1995:7) explains the expectation as preparing 'wise, compassionate, theologically astute and pastorally proficient servants who can lead the Church and our societies through the crisis of the Twenty-first century'. This is a daunting responsibility entrusted on the theological institutions that may be hard to fully accomplish. The expectations are in part unrealistic because the constituents fail to appreciate that theological education is a life-long process and a theological college can only engage part of that purpose. Cole says that it is merely an assumption that the type of information-oriented training we give to students will somehow translate into godliness (1991:39-40). These unrealistic expectations are probably why criticism has been leveled against these theological institutions for producing graduates who are functionally incompetent for the demands of pastoral ministry.

\section{Starting points for the Integrated Competency- Based Training Model}

The following starting points have proposed reforms that could address the observed weaknesses:

- The recovery of the church-in-mission as the ultimate goal and purpose of the theological education.

- A call for flexible content and course structure adjusted according to the developing needs of the student and the issues in the church and community.

- The call for flexibility must include an integration of the traditional model and alternative models of theological training. Besides lecturers, textbooks and class instruction include independent study, internship mentoring, modular courses, internet research, and discussion groups.

- The lecturers are to be viewed as facilitators and models to guide in the learning process. They should be active in pastoral ministry. The knowledge, experience and maturity of both the lecturer and student are of equal importance.

- Need for a strong experiential learning component whereby the student is to be actively involved in church and community ministry.

- A call for student evaluation to be based more on demonstrated competence in ministry rather than upon the grade point average (GPA). Efforts must be made to make the student learn well and intensively but not to merely satisfy the institutional requirements.

- A call for eclectic instructional methods. Less emphasis on the transmission mode and more emphasis on discovery, discussion and problem-centered projects.

- The need for close, personal relationships between students and faculty; students learn together through small groups or teams with the guidance of the faculty. The contacts should be both formal and informal.

- A call to develop an approach that takes seriously the need for ordered learning amongst adults within churches. Concepts such as self-directed learning, self-responsible learning, self-active learning and lifelong education.

These emerging starting points necessitate an innovation and a rethinking of how we should train emerging ministers both clergy and laity in the context of Africa. For long, the African church has relied heavily on a Western, formal theological education imported by Western missionaries to develop leaders. This has worked well to some extent. However, we have now realised how dysfunctional and inhibiting the Western model is to positioning the African leadership to respond to the needs of the ever growing church in Africa. Much money is being invested in theological schools, yet the leadership challenge has not been met in any meaningful way. A solution is therefore needed, and this article proposes for a new model of training that responds to the needs of the African church; a model that in our estimation would correspond to the early church forms of teaching.

\section{Principles of the Integrated-Competency Model}

In proposing this model of training, we do not lose sight of the purpose of the church. It is imperative that any model of theological training maintains the biblical image and the purpose of the church to 'equip the saints for the work of ministry' (Eph 4:11ff). A strong case can be made that the normative of such a model can be found in the New Testament. We are therefore proposing a Discipleship Model based on the commands of Jesus' command in Matthew 28:19-20: 'Go, make disciples, baptize them and teach them.' The discipleship type of model advocated for in this article is one that calls back the church to its roots of New Testament form and function, altering the way the church today perceives and practices theological education. The model advocates a shift from traditional, academic-based systems to church-based assessment procedures which integrate formal, nonformal and informal forms of theological preparation. 
The most normative model seen in the New Testament is the paradigm of Jesus and his disciples and Jesus approach to training his disciples was different than the education models of the cultural setting. According to Perkins (1990:2-22), Jesus utilised, in contrast to the normal approach to establish a rabbinic-style school, an intenerating context that generally took him away from the synagogue and school buildings, persuading his disciples to join him in the itineration. The process of training that Jesus modelled was close to the idea of training as an apprentice and in training as apprentice, 'priority is given to holistic growth for effective ministry rather than the common emphasis on the teacher conveying information for the student to seek to apply by themselves' (Harkness 2000:147). It is this sense of apprenticeship that lies behind the Greek word mathetes [disciple or learner]. The New Testament usage of the word would indicate a total attachment to someone in discipleship.

The approach adopted by Jesus with his disciples and which continued into the post-ascension development of the church is similar to what we are calling an Integrated CompetencyBased Training (ICBT). This approach, just as the paradigm represented by Jesus, can be described as integrated, formational and missional:

The characteristics of post-ascension discipling may be thus summarized as teaching which was intentional, relational, largely informal, communal, reciprocal and centrifugal. Such discipling was intended to result in each person becoming an active follower of Jesus and participant in his mission to the world ...

(Collinson 2000:15)

As opposed to the theological education of today where theory-practice is distinguished, the training of Jesus had the two (theory and practice) as one parcel where doing was a natural outcome of the being. The training ministry concentrated on producing men of God through a discipleship process.

The ICBT as a training model is designed to incorporate an integrated, formational and missional approach. This approach does well to recognise the missionary nature of the church [missio Dei]. As clearly articulated in the Great Commission, this is the most important command Christ gave to his church. It is to be the churches' preoccupation until Jesus comes back. It is the reason for the church's existence. The model for making disciples continues from generations to generation. The ICBT also advocates training these men and women in character development and ministry skills in addition to knowledge. This process mimics the Paul and Timothy model (2 Tim 2:2) of entrusting the gospel to faithful men involved in modelling and mentoring. To accomplish this, selection in ministry becomes a deliberate step of choosing people so as to transfer into them what we are and what we can do in and through Christ, in order that they may do the same to others.

The following principles recognise the search for an ICBT model of training; these principles contend that:
- Progress and permanence of the Christian faith is dependent on multiplying our influence by living out and instructing biblical values.

- The growth of the Kingdom of God in the world hinges on Disciples of Christ reproducing themselves. Through reproducing, a multiplication effect results, which leads to the growth of the Kingdom.

- The expectation in ministry is to carry on Jesus' ministry by instructing and training others in the precepts of the Christian faith and by so doing raise up faithful and dedicated learners who would grow to be fully devoted to Christ's lordship in their attitudes, actions, loyalties, priorities, and lifestyle.

- Ministry should develop a genuine concern for the lost that knows no geography, ethnic, linguistic or cultural boundaries.

These four principles suggest that our model of training must take into account the missionary nature of the church by integrating a functional orientation. All aspects of the training should be directed towards missions regardless of the discipline and the training done in the context in which the training student will function.

\section{Concept of integration}

An integrated approach to theological training has its basis in the biblical doctrine of the 'total person' or 'whole man'. The total person needs to be trained and developed. In theological training we should avoid unnecessary compartmentalisation. Integration is therefore not an attempt to maintain balance between academic, spiritual and the practical as though these things were done one at a time. Integration entails bringing these aspects together into a whole, and doing them at the same time. An integrated approach to theological education is academic, is spiritual, and is practical as each aspect necessarily presupposes, implies or contains the other (Chow 1982:52).

Cole (2001:215) says the approach to training for ministry must be holistic. A holistic approach to curriculum of training for ministry employs a combination of the domains of learning with the different training outcomes of knowledge, character and ministry skills.

The advantage of integration is that it helps equip ministers with adequate comprehensive skills with which to address the diversified felt-needs of the laity.

\section{Competency-based approach}

The objective of theological training responds to the students' needs, producing growth in knowledge, maturity in character development and competence in ministry skills. Students progressively grow in relationship to God as they explore the tensions between their experiences, the Bible's teaching and their individual response in obedience. This being the objective of theological education, a better way to encourage this process is to apply the elements of competency-based learning. As a curricular model, competency-based learning 
seeks to develop competencies in persons at different stages of their maturation journey. The competencies encompass the development of the whole person: affect understanding, character, and skills. Competency-based learning does not focus on courses and grades but on measuring competencies based on designed outcomes.

In contrast to the Content-Transmission Model that relies on subject matter as the organising principle, the Competency-Based Model is a flexible representation that provides a framework for learning in a variety of contexts. In the Content-Transmission Model, excellence is measured mainly by the nature of the process and not by the product as is with theological training. The criterion of excellence in the competency-based learning is the extent to which the graduate is ready for functioning effectively in that ministry, showing potential for continued development (Youngblood 1989:29).

\section{The basis for Integrated Competency-Based Training Model}

Four fundamental questions were used to form the basis for an integrated competency-based ministerial training. The first question is what competencies should ministerial trainees' possess? This question focuses on the selection of the outcome that the training will help students reach. The list of competencies is developed, firstly from gleaning principles from the Scriptures as to what a competent church minister looks like and secondly, from research as to what a competent minister is perceived to look like in their context of ministry.

The most significant characteristics or criteria that people across denominational lines are looking for in their ministers are the following, in order of preference (Chow 1982:52):

- Sacrifice without regard for acclaim. This means a minister who is able to accept personal limitations and is able to serve without concern for public recognition.

- Personal integrity. Able to honour commitments by carrying out promises despite pressure to compromise.

- Christian example. The minister should be one whose personal belief in the gospel manifests itself in generosity and, in general, in Christian example that people in the community can respect.

- Pastoral skills. People want a minister who shows competence and responsibility by completing tasks and by being able to handle differences of opinion, and who senses the need to continue to grow in spiritual skills.

- Leadership. The minister must be able to build a strong sense of community within a congregation. Taking time to know the people in his church and developing a sense of trust and confidence between the congregation and himself.

The second question to be asked is: 'What knowledge, skills and attitude do the ministerial trainees currently possess?' This question acknowledges that each trainee already has been formed by informal and formal means that requires prescribed sources to meet his present developmental needs. This question intends to diagnose the learner's needs. This need is defined as 'the gap between the present level of competencies and a higher level required for effective performance' (Knowles 1980:88).

Thirdly, how can ministry trainees participate in value added experiences that contribute to the desired outcome? On focus here is the selection of learning activities most appropriate for producing a competent Christian minister. This may include learning contracts, mentoring, internships, or specific training modules of instruction within the student's context. The training of church workers must be conducted in 'light of personal, situational and contextual demands of biblical norms and cultural dimensions' (Cole 1991:42). The selection of learning activities should reflect both spiritual and character development as it prepares a student to minister in Word and life as a true believer.

The fourth question is 'how will we know when the ministerial students have changed, acquired new understanding, deepened their character, examined their attitude and sharpened their skills?' The focus here is evaluation. Evaluation in the competency-based training is an integral part of the whole process.

To qualify for training, the students need to be able to do more than passively collect and casually dispense information on command. They must be a living, active and personal demonstration of the biblical truth they have learnt and are capable of giving insight and proposing initiatives (Youngblood 1989:28). Despite the difficulty in evaluating spiritual formation in objective and measurable ways, this is a base against which spiritual and character development should be monitored. In addition, for one to claim to have been trained, the qualities and behavior of the Christian minister within the church must have been taught, modelled and stimulated within the training programme. Ability to feed and tend the flock and make disciples would demonstrate competency. Excellence in theological training should therefore be measured in terms of the servant hood quality that the student possesses and the effectiveness of ministry which he performs. This will involve both being and doing in addition to knowing.

\section{The Illustrated Model}

The Integrated Competency-Based Model of Training can be illustrated in Figure 2.

\section{Implementation of the Integrated Competency-Based Training Model}

The following are suggestions for implementing an Integrated Competency-Based Training Model within or without the context of an existing residential theological college.

\section{Recruitment for ministerial training}

Strict entrance criteria must be put in place. This implies a specific and selective recruitment. Ministerial training should only be for those who have sensed God's calling for ministry 


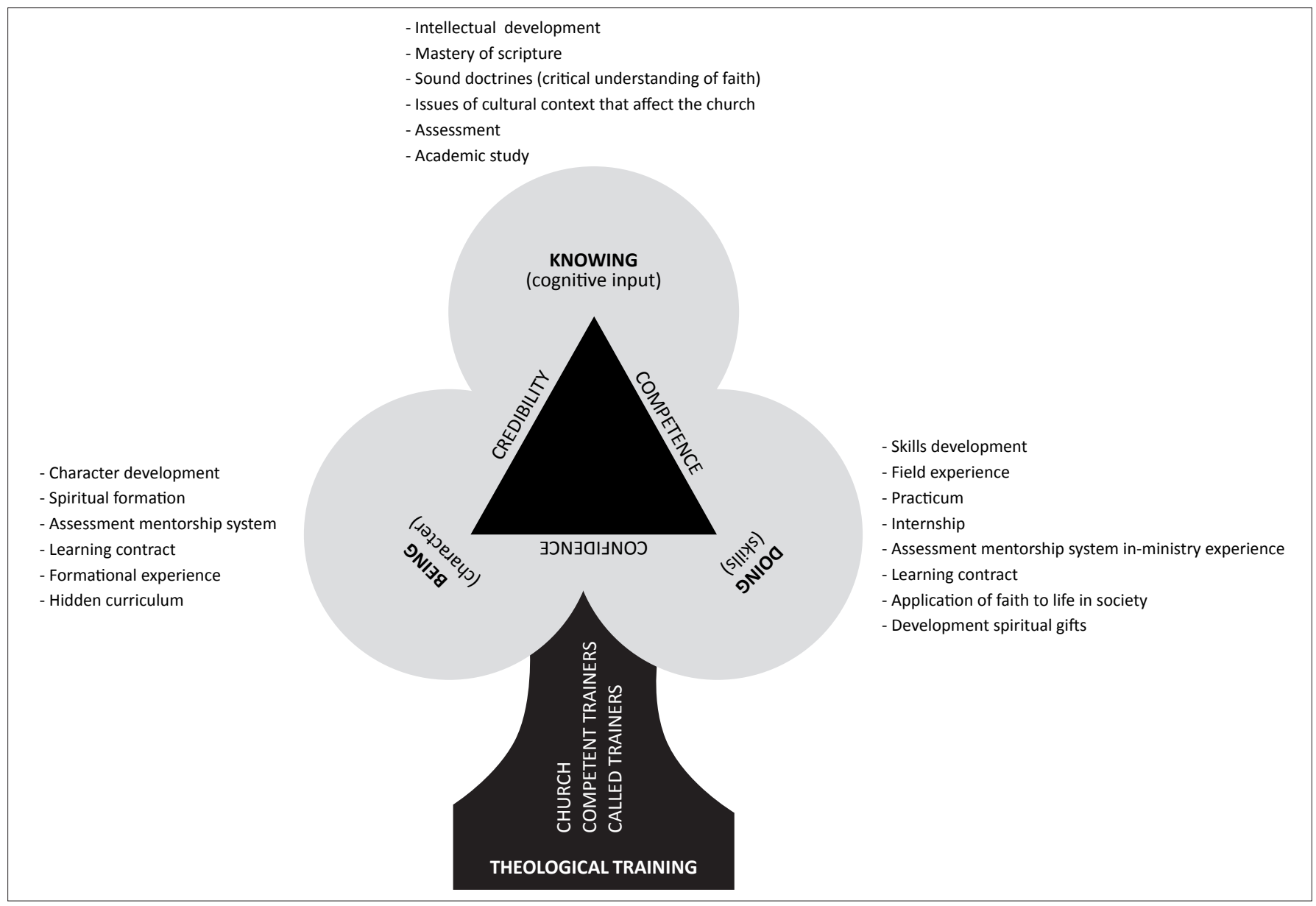

FIGURE 2: Illustrates the proposed model of ministerial training - Integrated Competency-Based Model.

since ministerial training does not impart the pastoral vocation or spiritual gifts necessary to exercise that calling. The criteria for applicants who seek pastoral training should include: a demonstrated passion for ministry, a clear sense of calling, evidence of service in the local church and an average academic achievement. The local church is most likely to value the student and thus place him or her in ministry.

\section{Academic study}

Godly character is necessary, but for a minister it is not sufficient. He needs to be trained in the Word. What he is taught needs to be biblical and contextual. The 'knowing' (book knowledge) aspect of training should not be minimised or treated as secondary. The training must, however, go beyond content-oriented teaching or learning experience, to include the development of a spirit of investigation that becomes part of the student's life.

\section{Curriculum and context}

In the integration of the curriculum, contextualisation must take on a significant role. Whilst the curriculum must be biblically centered, it must at the same time interrelate and be relevant to the local context of the student. The curriculum must be context-sensitive and must take into consideration the needs of the specific society and culture. This approach will avoid the uncritical employment of curriculum 'importation' from a different context. Specifically, an Africa curriculum must address the needs of Africans. Nunez (1986) says that:

if in order to establish a curriculum we do not take into account our cultural and social reality, we are forming decontextualized thinkers and theologians, or activists who are equally cut off from their social environment.

(Nunez 1986:76)

\section{Courses and content}

The individual courses in the curriculum must also be integrated by way of content organisation and teaching method. How a course is taught is as important as what is taught. The courses should be such that they are developed to bring content, skills and attitude development to the point that the student is able to apply the ability with excellence. Selection of content should be based on significant goals and objectives.

\section{Field work}

By its very nature, ministry is both 'taught and caught'. Theological education within classroom walls can be too theoretical. Thus, theological institutions should create a field education programme, and then appoint a director to coordinate field education for the students and to liaise between the institute and the churches for the practical work of the students as well as for their placement after graduation. 
Fieldwork should be part of the curriculum with academic credits so that a student cannot graduate from the training without having satisfactorily completed the requirements in the fieldwork. Field education will also serve as a means where pastors in churches will participate in the training of students through their supervision in the field: 'Theological schools must not serve as ivory towers removed from the real day-to-day situations in the churches for which candidates are being trained ...' (Cole 1991:42)

\section{Communal activities}

Communal activities outside classroom should be a deliberate part of the programme. This includes retreats, spiritual exercises week, communal meals, mission week and outings. These occasions are necessary to create solidarity amongst faculty and students. These communal activities could be used as teaching methods that enable the students to practice skills in an informal and relaxed atmosphere. Mutual sharing of experiences, feelings, viewpoints and areas of concern can prove to be profitable to the training and learning. In the Integration Model, the curriculum must reflect both spiritual and character development as it prepares a student to minister in word and life as a true believer.

\section{Mentorship systems}

Faculty members should be required to have a visible personal interest in the students and their welfare. To understand the needs of the students, the relationship between them and faculty should be one of dealing with a friend, a mentor, and a colleague. This means that trainers in a theological school should demonstrate concern for students' ministry and calling. Mentoring will create an atmosphere of nurture in which students see ministry modelled before them. Because of the importance of godly behaviors and attitudes in theological training, what the teacher does becomes more important than what he says. Modelling involves learning by observation and teachers model when they exhibit behavior in the presence of their students. Mentoring has much to offer because it provides both character and professional development.

\section{Faculty recruitment}

The qualification of teaching staff is critical in this training model. A careful selection of personnel is the key to achieving the training objectives. Willingness to undergo mentoring process and the acceptance of mentoring as a part of ministerial training should be a criteria for the employment of faculty. As academicians entrusted with the spiritual nurturing of students, faculty must learn to present a more biblically-based model of Christian discipleship. The spiritual formation and development of students begins with and depends on the spirituality of the faculty. There is need to recruit faculty members who are actively involved in their local churches.

\section{Continuity}

The process of training ministers should not be considered complete upon graduation. The school should continue to offer graduates more learning opportunities. Short courses on current issues and informal training programmes should continue to be offered to alumni. This commitment to continuity recognises that the process of learning is beyond the formal relationship with the school; it also requires encouragement and is best achieved in the community context, not isolation.

\section{Conclusion}

The integrated competency-based training approach can be applied to any model of training, be it formal or informal. To be adopted in the traditional model of theological training residential seminary - it will require some radical changes to the existing structures. These changes include an integrated, programmatic approach that comprises the academic, spiritual, and practical components. The proposed model offers a creative approach to theological training, designed to aid in the development of the whole person whilst at the same time advancing the competence of pastors in their ministerial roles. This has been proved to provide holistic ministerial training that is characterised by knowledge of the Bible, spiritual development and practical training on how to handle church ministry.

\section{Acknowledgements Competing interests}

The authors declare that they have no financial or personal relationship(s) which may have inappropriately influenced them in writing this article.

\section{Authors' contributions}

The contents of this article forms part of the $\mathrm{PhD}$ degree of J.K.M. Because he lived in Kenia, his promoter, B.J.D.K., compiled out of his $\mathrm{PhD}$ thesis this article from one of his chapters.

\section{References}

Banks, R., 1999, Re-envisioning theological education: Exploring a missional alternative to current models, Wm. Eerdmans, Cambridge.

Chao, J., 1976, 'Education and Leadership', in The New Face of Evangelicalism: An International Symposium on the Lausanne Covenant, pp. 43-56IVP, Chicago, IL.

Cheesman, G., 1993, 'Competing Paradigm in Theological Education Today', Evangelical Review of Theology 17(4), 484-499.

Chow, W.W., 1982, 'An Integrated Approach to Theological Education', in P. Bowers (ed.), Evangelical Education Today, pp. 49-60, Eerdmans Publishing Company, Grand Rapids, MI.

Cole, V.B., 2001, Training of Ministry: A Macro-Curriculum Approach, Theological Book Trust, Bangalore.

Cole, V.B., 1991, 'The Training of Leaders for the Ministry: Implications for Theological Education', Africa Journal of Evangelical Theology 10(42).

Collinson, S., 2000, 'Making Disciples: An Educational Strategy for use Beyond the Time of Jesus?', Journal of Christian Education 43(3), 7-18.

Dearborn, T., 1995, 'Preparing New Leaders for the Church of the Future', Transformation 12(4), 7-12.

Feilding, C.R., 1966, Education for Ministry, American Association of Theological Schools, Dayton, $\mathrm{OH}$.

Harkness, A., 2000, 'De-schooling Christianity in the New Millenium', Journal of Christian Education 43(3), 46-54.

Hill, B.V., 1997, 'Evaluating the Schooling Paradigm: Curriculum for life?', in J. Short \& T. Cooling (eds.), Agenda for Biblical Change, n.p., Appolos, Leicester.

Kinsler, F.R., 1983, Ministry by the people: Theological education by extension, WCC, Geneva/Orbis Books, Maryknoll, NY. 
Mayers, M.K., Richards, L. \& Webber, R., 1972, Reshaping evangelical higher education, Zondervan Publishing House, Grand Rapids, MI.

Morgan, T.C. \& Giles, T.S., 1994, 'Re-engineering the Seminary', Christianity Today 24(October), 71-78.

M.J. Murdock Charitable Trust Review, 1995, 'A 21st Century faculty model: Review of Graduates Theological Education in the Pacific Northwest', Faculty Dialogue of Graduates The
23(Winter), 9-24.

Niebuhr, H.R., Williams, D.D. \& Gustafson, J.M., 1957, The advancement of theological education, Harper and Brothers, New York.

Nunez, C.E., 1986, 'The problem of Curriculum', in R. Padilla (ed.), New Alternatives in Theological Education, pp. 73-80, Regnun Books, Grand Rapids, MI.
Perkins, P., 1990, Jesus as teacher, Cambridge University Press, Cambridge.

Reed, J., 1995, 'Church Based Theology: Creating A New Paradigm', in BILDInternational Conference Proceedings, Learncorp, Ames, IO, May 05, 1995, pp. $1-32$.

Rooy, S., 1988, 'Historical Models of Theological Education', in C.R. Padilla (ed.), New Alternatives in Theological Education, pp. 51-72, Regnum Books, Oxford.

Wright, J., 2007, 'Training Leaders: A Functioning Model for Missionaries ', Evangelical Missions Quarterly (July) 42(3).

Youngblood, R.L., 1989, Excellence and renewal: Goals for accreditation of theological education, Paternoster Press, Exeter. 